\title{
Honouring loved ones who have passed: bringing grief into the pedagogical frame during the pandemic
}

\author{
Farrukh Akhtar \\ Kingston University, UK
}

Keywords: Covid-19; grief; bereavement; pedagogy; pedagogical frame; belonging.

\section{The challenge}

It takes discipline to learn: to create a dedicated space in the franticness of our lives in which we can be grounded and focused. This is not easy at the best of times. During a pandemic it is even harder. When that pandemic leads to the loss of loved ones - the very loved ones that acted as a source of support - it is unsurprising if, along with the extinguishing of an important light in our lives, some other vital thing is lost: the vibrant space in which learning took place.

As a course leader in a post-1992 university, I am regularly notified about student life events. As the pandemic progressed, I was aware of over 30 students suffering bereavements, predominately from black and minority ethnic (BME) backgrounds. I thought of them studying, grieving at home during lockdown, without the usual buffer of rituals and connections to wider community. Hughes (2019) refers to the need to normalise heightened situations, to give the message that we are all in this together. However, it was clear this was not so. It felt like the dead were amassing steadily, with the bell tolling more in some quarters. Some students suffered multiple losses within a frighteningly short timeframe, family members dying within weeks of each other, in different parts of the world.

Notifications grew; students reported their losses, steadily withdrawing. Then two exemplary students vanished after suffering bereavements. They did not respond to emails, phone calls, letters, or colleagues' entreaties. It seemed the academy had no space for grief. It was 'disenfranchised' (Doka, 1989). 
The whole student group appeared to lack the resources to emotionally reach out to their grieving peers. Their expectation was the university should provide this 'support'. Referrals to student counselling felt grossly inadequate. A narrative of rage was developing amongst the students blaming an inflexible and persecutory institution that offered no support. A fairly collegial community was being wrenched apart, leaving me feeling powerless. I was concerned about students' welfare and wanted to re-assure them that, with time, the resumption of studies was not only possible, but could act as a resource.

\section{The response}

Corr (1999) talks of 'enhancing the concept of disenfranchised grief' (p.1), embracing it in its broadest sense. It felt imperative to move beyond the normal pedagogical frame, to acknowledge loss, in a powerful show of togetherness and inclusion (Goldman, 2017). Instead of grief being cast to the side-lines of the academy, we would acknowledge it and give it centre-space, by holding an event for students to celebrate the lives of loved ones who had passed.

My thinking was influenced by Weller's (2015) ideas: by taking the smallest steps in acknowledging grief, the wounded part of us feels met. Nwoye's (2005) focus on the role of community in managing grief was also pertinent. Whatever students' faith or cultural background, we would collectively share small acts of remembrance to help us find the way through grief, towards healing.

My initial explorations with colleagues met with caution. Grief can seem boundless and colleagues rightly expressed concern about creating a safe enough space online. However, they agreed it was worth exploring. There was a risk in taking action, but also one in doing nothing.

Student engagement and co-production felt essential. All students were invited, 17 registered to attend, and three to contribute. We discussed how they could do this. Although time consuming, this process was as important as the event itself, giving agency to students, and hopefully, a message of belonging (Hughes, 2019). Together, we carefully organised an hour-long online event. 
On the day, the students spoke with quiet dignity about loved ones, sharing stories that sprung to mind. The shared experience of loss united us as we listened and many responded with verbal comments, or through the chat box. Loved ones who had passed were brought 'into the room' through our respectful presence. We also celebrated the lives of two faculty staff members who had passed away. There was an open space, in which anyone could speak if they felt moved to, and music. To close, we brought the focus back to the living, to self-care and how small acts of remembrance can help the grief process. There were a couple of silent minutes, in which students could reflect or light a real or virtual candle, closing with music.

The hour-long event was incredibly moving. Student comments included thanks for a 'powerful session' and that it was 'good to be supported in such times'. There was a sense of gratitude with students commenting on the blessing of shared stories and memories. Through the event we all felt deeply connected with each other. In the staff debrief afterwards, one colleague said that the event had been 'amazing'. Another said that it had 'opened up the kind of learning opportunities possible'. Its impact reverberated for some time, gently resourcing and strengthening our fragile learning community. In giving grief centre space, it lost the edges of its 'otherness', was more accepted, opening up hope. This shift to hope is important. Swartwood et al. (2011) refer to the exchange of hope in online grief communities as a way of validating grief and the move towards healing.

\section{Recommendations}

The session emerged from a need to be locally responsive to the whole student experience, to maintain a sense of community. Discernment is needed to identify such issues and courage to extend the pedagogical frame to address them.

Careful planning with trusted colleagues is a must. Educators need to ensure that they feel adequately resourced, and are supported in the emotional labour (Hochschild, 1983) inevitably involved. 
Co-production with students maximises engagement. Use of online resources such as polls ensures every student has a voice. However, this does not replace the personal touch. Approaching less vocal students builds on their strengths and contributes to inclusivity.

Our relationship to online learning has been changed forever by the pandemic. This example demonstrates real opportunities to use online tools to strengthen student mental health and to develop community and a greater sense of belonging for all students.

\section{References}

Corr, C. A. (1999) 'Enhancing the concept of disenfranchised grief', OMEGA - Journal of Death and Dying, 38(1), pp.1-20. https://doi.org/10.2190/LD26-42A6-1EAV-3MDN.

Doka, K. J. (1989) 'Disenfranchised grief', in Doka, K. J. (ed.) Disenfranchised grief: recognizing hidden sorrow. Lexington, MA: Lexington Books, pp.3-11.

Goldman, L. (ed.) (2017) Creating inclusion and well-being for marginalized students: whole-school approaches to supporting children's grief, loss, and trauma. London: Jessica Kingsley Publishers.

Hochschild, A. R. (1983) The managed heart: commercialization of human feeling. Berkeley: University of California Press.

Hughes, G. and Spanner, L. (2019) The university mental health charter. Leeds: Student Minds.

Nwoye, A. (2005) 'Memory healing processes and community intervention in grief work in Africa', Australian and New Zealand journal of family therapy, 26(3), pp.147-154. https://doi.org/10.1002/j.1467-8438.2005.tb00662.x.

Swartwood. R. M., Veach, P. M., Kuhne, J., Lee, H. K., Ji, K. (2011) 'Surviving grief: an analysis of the exchange of hope in online grief communities', OMEGA - Journal of Death and Dying, 63(2), pp.161-181. https://doi.org/10.2190/OM.63.2.d. 
Weller, F. (2015) The wild edge of sorrow: rituals or renewal and the sacred work of grief. California: North Atlantic Books.

\section{Author details}

Farrukh Akhtar is an Associate Professor at Kingston University. She is a national Teaching Fellow, and author of Mastering social work values and ethics (JKP) and Preparing the ethical toolkit: balancing rights and responsibilities (Palgrave). She has published in The Journal of Social Work Practice, Writing in Practice, Working with Older People, BMC Geriatrics, and others. 